\title{
The effect of nitrogen fertilization on the incidence of olive fruit fly, olive leaf spot and olive anthracnose in two olive cultivars grown in rainfed conditions
}

\author{
M. Ângelo Rodrigues ${ }^{\mathrm{a}, *}$, Valentim Coelho ${ }^{\mathrm{a}}$, Margarida Arrobas ${ }^{\mathrm{a}}$, Eugénia Gouveia ${ }^{\mathrm{a}}$, \\ Soraia Raimundo ${ }^{a}$, Carlos M. Correia ${ }^{b}$, Albino Bento ${ }^{a}$

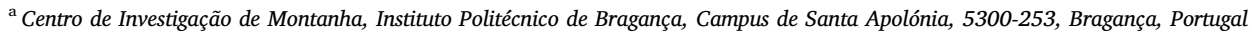 \\ ${ }^{\mathrm{b}}$ Centre for the Research and Technology of Agro-Environmental and Biological Sciences (CITAB), University of Trás-os-Montes e Alto Douro, Vila Real, Portugal
}

\section{A R T I C L E I N F O}

\section{Keywords:}

Oleae europaea

Bactrocera oleae

Spilocaea oleaginea

Colletotrichum gloeosporioides

Nitrogen fertilization

Olive yield

\begin{abstract}
A B S T R A C T
Pests and diseases can cause significant loss of olive yield and/or justify control measures with pesticides which are harmful to the environment. Several agroecological variables, such as fertilization, can favour or limit the incidence of pests and diseases. However, in olive, few studies exist on the subject than can assist in the implementation of more sustainable phytosanitary measures. In this study the effect of nitrogen fertilization $(0,20$, 40 and $120 \mathrm{~kg} \mathrm{~N} \mathrm{ha}^{-1}$ ) on the incidence of olive fruit fly (Bactrocera oleae), olive leaf spot (Spilocaea oleaginea) and olive anthracnose (Colletotrichum gloeosporioides) was evaluated in two olive orchards of the cultivars 'Cobrançosa' and 'Madural'. The study took place in 2017 and 2018 in Lombo, NE Portugal. Nitrogen fertilization significantly increased olive yield and nitrogen concentrations in plant tissues and induced a delay in fruit maturity. The incidence of the olive fruit fly was significantly lower in the more fertilized treatments of both cultivars. However, 'Madural' showed itself to be more susceptible than 'Cobrançosa' to olive fruit fly. The effect of nitrogen on the reduction of the incidence of the olive fruit fly was attributed to the delay caused in fruit maturation, which might have desynchronized the attractiveness of the fruits for insects to lay their eggs on their flight curve. In contrast, olive leaf spot and olive anthracnose were not influenced by nitrogen fertilization. As a result, nutrient management in olive groves must balance carefully the requirements of economic rationality with environmental preservation, particularly with regard to the harmful relationship between the use of excessive nitrogen rates and several adverse environmental effects.
\end{abstract}

\section{Introduction}

Nitrogen is a key element in ecosystem productivity, and is usually used as a fertilizer in virtually all agricultural crops. However, of the nitrogen applied as a fertilizer, the percentage used by plants is low, and gets progressively lower as the applied rates increase (Rodrigues et al., 2005, 2006; Arrobas et al., 2011). A significant part of the nitrogen applied as a fertilizer is lost from the soil mainly by ammonia volatilization, nitrate leaching or denitrification (Coyne, 2008; Mulla and Strock, 2008; Havlin et al., 2014). Nitrogen escaping from agricultural soils can contaminate water bodies causing eutrophication (Yang et al., 2018; Poikane et al., 2019). Nitrates in drinking water and high levels of nitrates in edible vegetables may cause methemoglobinemia and several other human diseases (Espejo-Herrera et al., 2015;
Schullehner et al., 2018). Gaseous forms of nitrogen leaving the soil, in particular nitrogen oxides, may contribute to global warming and to ozone layer depletion (Bronson, 2008). Thus, nitrogen must be judiciously used on agricultural crops, the rates being adjusted to crop needs to maximize its use efficiency and to reduce the losses to the environment.

While studies of the effect of nitrogen on crop yield and nutrient use efficiency are abundant, studies on the effect of nitrogen fertilization on the incidence of pests and diseases are very limited. The fact that nitrogen has the potential to affect canopy structure and microclimate, plant composition, gene expression and the release of attractive volatile organic compounds, may significantly influence the incidence of pests and diseases, which in turn is related to the number of phytosanitary treatments, their environmental impact and farmers' profit. From the

\footnotetext{
* Corresponding author.

E-mail addresses: angelor@ipb.pt (M.Â. Rodrigues), valentimcoelho@ipb.pt (V. Coelho), marrobas@ipb.pt (M. Arrobas), egouveia@ipb.pt (E. Gouveia), soraia-raimundo@live.com.pt (S. Raimundo), ccorreia@utad.pt (C.M. Correia), bento@ipb.pt (A. Bento).
} 
studies conducted up to the present, we can find quite different results, but in some of them nitrogen fertilization was found to increase the incidence of several diseases. For instance, it was reported that high amounts of nitrogen fertilization increased the infection of winter wheat (Triticum aestivum) by fusarium foot and root disease (Fusarium culmorum) (Hemissi et al., 2018), resting spore production of clubroot caused by Plasmodiphora brassica on rapeseed (Brassica napus) (Aigu et al., 2018), fusarium head blight (Fusarium sp.) and related mycotoxin accumulation on winter wheat (Heier et al., 2005), powdery mildew (Erysiphe graminis hordei) in winter barley (Hordeum vulgare) (Oerte and Schönbeck, 1990) or gummy stem blight (Didymella bryoniae) on watermelon (Citrullus lanatus) (Santos et al., 2009). In comparison, the effect of nitrogen fertilization on increasing incidence of pests is less common. However, Gash (2012) observed that in the cereal aphid (Metopolophium dirhodum), the intrinsic rate of increase and fecundity increased with each level of nitrogen applied in winter wheat.

Studies where the effect of nitrogen reduced the incidence of pests or diseases are also not uncommon. Vos and Frinking (1997) observed a negative correlation between nitrogen levels and the incidence of blossom mould and thrips in hot pepper (Capsicum spp.) under tropical lowland conditions. David et al. (2003) stated that nitrogen fertilization could help reduce powdery mildew (Erysiphe cichoracearum) incidence in Hiemalis begonia in the greenhouse. Cao et al. (2013) reported a decreased host susceptibility to bacterial cancer (Pseudomonas syringae pv. syringae) in stone fruit species, such as peach (Prunus persica), prune (Prunus domestica) and almond (Prunus dulcis). Lecompte et al. (2010) observed that the overall disease severity of Botrytis cinerea was lower in tomato (Solanum lycopersicum) plants with higher nitrogen inputs. Veromann et al. (2013) observed that dark spot disease (Alternaria brassicae) levels decreased with increasing nitrogen availability in rapeseed.

However, a poor or only tenuous relationship between nitrogen fertilization and the incidence of pests or diseases has also been recorded. Relevant examples found in the literature are the incidence of Septoria tritici in wheat (Robert et al., 2006), leaf rust (Puccinia triticina) in wheat (Robert et al., 2005; Carretero et al., 2011), fusarium head blight (Fusarium graminearum) and mycotoxin levels in winter wheat (Krnjaja et al., 2015), bacterial fruit blotch (Acidovorax citrulli) in melon (Cucumis melo) (Zimerman-Lax et al., 2016), and several pests and diseases in rapeseed (Veromann et al., 2013).

Olive (Olea europaea L.) is a crop of high economic and social importance in the Mediterranean basin. Olives and olive oil are some of the most iconic elements of the Mediterranean diet due to their beneficial effects for human health. The benefits of olive oil in human health have been associated to well-balanced fatty acid composition and the presence of vitamins and natural antioxidants (Medeiros, 2001; Usanmaz et al., 2018). The consumption of olive oil can reduce LDL cholesterol, the potential risk of several cancers and provide some protection against cardiovascular and neurodegenerative diseases (Covas, 2007; Pérez-Jiménez et al., 2007). Regarding nitrogen fertilization studies on the olive tree performance, they have not always reported similar findings, with some results showing a good response (Erel et al., 2013; Morales-Sillero et al., 2009; Rodrigues et al., 2011, 2015) and others in which this did not occur (Fernández-Escobar et al., 2009a, b). However, although the use of nitrogen as a fertilizer is a common practice among olive growers, the relationship between nitrogen fertilization and the incidence of pests and diseases has not yet received due attention, given that such data could help in the establishment of rational fertilization programs. Having said this, Roca et al. (2018) studied the influence of nitrogen fertilization on olive leaf spot (S. oleaginea) development on the susceptible cultivar 'Picual' in hydroponic culture, potted plants and mature olive trees. Plants or detached leaves were artificially inoculated with a conidial suspension of the pathogen. A significant increase in shoot growth, chlorophyll and nitrogen concentration in leaves, and disease incidence, was observed in plants subjected to a high nitrogen treatment. In spite of the importance of olive, as far as we know, no other studies exist reporting the effect of nitrogen fertilization on pests or diseases in this crop.

Olive leaf spot (S. oleagina), olive fruit fly (B. oleae) and olive anthracnose (C. gloeosporioides) are some of the most important phytosanitary problems of olive. Olive leaf spot appears in late spring as dark spots on the upper surface of the leaves. Dark spots evolve during the growing season as a yellow halo around each spot. Symptoms may also appear on the stem and fruit, but are most common on the leaf surface. Olive leaf spot can cause significant losses in yield due to defoliation and in severe cases twig death (Trapero et al., 2017). The olive fruit fly is a phytophagous species, whose larvae feed on the fruit of olive trees. It is considered the most serious pest of olives in the regions where it lives, significantly affecting both the amount and quality of production (Alvarado et al., 2017). Larvae of second and especially third stages, by removing a significant proportion of the pulp, reduce olive yield. Part of the production is also lost due to premature falling of the attacked fruit. The holes dug by the larvae favour the oxidation of the remaining pulp and the establishment of olive anthracnose, significantly reducing the quality of the olive oil. Olive Anthracnose, in turn, is widespread in most olive-growing countries, causing significant yield losses, poor fruit and oil quality. It is usually seen as the most important fungal disease of olive fruit in humid olive growing regions. The most typical symptom of olive anthracnose is fruit rot and mummification (Trapero et al., 2017).

The objective of this study was to evaluate the effect of nitrogen applied to the two most important cultivars grown in rainfed olive orchards in NE Portugal ('Cobrançosa' and 'Madural') on the incidence of olive leaf spot, olive fruit fly and olive anthracnose. Taking into account that it is usual to generalize that nitrogen fertilization tends to aggravate the incidence of pests and diseases, they were set as working hypotheses that the incidence of olive leaf spot, olive anthracnose and olive fruit fly increase with the rate of nitrogen applied. The study is based on field trials from commercial orchards of mature trees to allow the integration of the ecological variables that determine the incidence of diseases and pests and also olive yield, the main component of the farmer's profit.

\section{Materials and methods}

\subsection{Experimental conditions and field determinations}

The experiments were carried out during two growing seasons (2017 and 2018) in two rainfed olive groves, one of the cultivar 'Cobrançosa' and the other of the cultivar 'Madural', both trials located in Lombo, Bragança district, in NE Portugal, at the coordinates 41.446556, -6.822067 and 41.457075, -6.832459, respectively. The orchard of the cultivar 'Cobrançosa' is 18 years old and the orchard of 'Madural' is 50 years old. 'Cobrançosa' and 'Madural' are the two most representative cultivars of the Protected Designation of Origin (PDO) 'Azeite de Trás-os-Montes' (Trás-os-Montes olive oil). They are both well suited to drought producing olive oil of excellent quality.

The region benefits from a Mediterranean type climate. Meteorological data recorded during the experimental period is shown if Fig. 1. The soils of both orchards are Leptosols originating from a bed rock of schist. Some physicochemical properties determined from soils samples collected when the trial started in the $0-20 \mathrm{~cm}$ surface soil layer are presented in Table 1.

In the orchard of 'Cobrançosa' four nitrogen fertilizer rates [0 (N0), 20 (N20), 40 (N40) and 120 (N120) $\mathrm{kg} \mathrm{N} \mathrm{ha}^{-1}$ ] were imposed and in the orchard of 'Madural' three [0 (N0), 40 (N40) and 120 (N120) kg $\left.\mathrm{ha}^{-1}\right]$. These fertilization regimes were applied to three groups (three replicates) of two equally sized trees. The fertilizer used was ammonium nitrate $20.5 \% \mathrm{~N}\left(50 \% \mathrm{NH}_{4}{ }^{+}, 50 \% \mathrm{NO}_{3}\right.$-). In addition to the nitrogen fertilization treatments of the experimental design, all trees received a basal fertilization plan with the equivalent of $17.5 \mathrm{~kg} \mathrm{P}^{-1}$ $\left(40 \mathrm{~kg} \mathrm{P}_{2} \mathrm{O}_{5} \mathrm{ha}^{-1}\right), 33.2 \mathrm{~kg} \mathrm{~K} \mathrm{ha}^{-1}\left(40 \mathrm{~kg} \mathrm{~K}_{2} \mathrm{O} \mathrm{ha}^{-1}\right)$ and $2 \mathrm{~kg} \mathrm{~B} \mathrm{ha}^{-1}$. The fertilizers used were, respectively, superphosphate $\left(18 \% \mathrm{P}_{2} \mathrm{O}_{5}\right)$, 


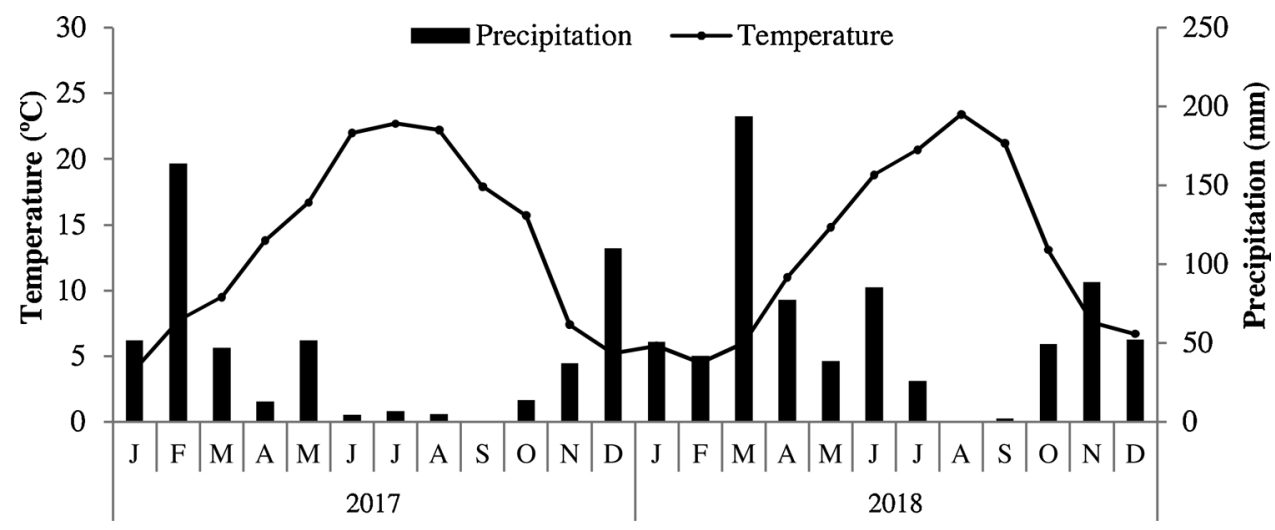

Fig. 1. Average monthly temperature and accumulated precipitation in the Meteorological station of Santa Apolónia Farming in Bragança.

Table 1

Selected physical and chemical properties of soil samples $(0-20 \mathrm{~cm})$ taken at the beginning of the experiments.

\begin{tabular}{lll}
\hline Soil properties & Madural & Cobrançosa \\
\hline Sand (\%) & 78.9 & 77.7 \\
Silt (\%) & 18.1 & 18.9 \\
Clay (\%) & 3.0 & 3.4 \\
Texture & Loamy-sand & Loamy-sand \\
pH $\left(\mathrm{H}_{2} \mathrm{O}\right)$ & 5.6 & 5.9 \\
${ }^{1}$ Organic carbon $\left(\mathrm{g} \mathrm{kg}^{-1}\right)$ & 0.89 & 0.46 \\
${ }^{2}$ Extractable $\mathrm{P}\left(\mathrm{mg} \mathrm{P}_{2} \mathrm{O}_{5} \mathrm{~kg}^{-1}\right)$ & 158 & 48.3 \\
${ }^{2}$ Extractable $\mathrm{K}\left(\mathrm{mg} \mathrm{K}_{2} \mathrm{O} \mathrm{kg}{ }^{-1}\right)$ & 107 & 81.5 \\
${ }^{3}$ Extractable B $\left(\mathrm{mg} \mathrm{kg}^{-1}\right)$ & 4.23 & 1.89 \\
${ }^{7}$ Exchangeable $\mathrm{K}\left(\mathrm{cmol}^{+} \mathrm{kg}^{-1}\right)$ & 0.31 & 0.11 \\
${ }^{7}$ Exchangeable $\mathrm{Na}\left(\mathrm{cmol}^{+} \mathrm{kg}^{-1}\right)$ & 0.15 & 0.31 \\
${ }^{7}$ Exchangeable Ca $\left(\mathrm{cmol}^{+} \mathrm{kg}^{-1}\right)$ & 6.84 & 7.41 \\
${ }^{7}$ Exchangeable $\mathrm{Mg}\left(\mathrm{cmol}^{+} \mathrm{kg}^{-1}\right)$ & 1.08 & 1.01 \\
${ }^{7}$ Exchangeable acidity $\left(\mathrm{cmol}^{+} \mathrm{kg}^{-1}\right)$ & 0.30 & 0.25 \\
\hline
\end{tabular}

${ }^{1}$ Walkley-Black; ${ }^{2}$ ammonium lactate; ${ }^{3}$ Hot water, azomethine-H; ${ }^{4}$ ammonium acetate.

potassium chloride $\left(60 \% \mathrm{~K}_{2} \mathrm{O}\right)$ and borax $(11 \% \mathrm{~B})$. In addition to fertilization, the plants were subjected to light annual pruning ( $\sim 10 \%$ removal of the canopy) and the weeds were controlled with the application of a non-selective, post-emergence herbicide $\left(3 \mathrm{~kg} \mathrm{ha}^{-1}\right.$ of glyphosate isopropylamine salt) applied in early April.

In July of each year, at endocarp hardening, and in December, during the resting period of olive, leaf samples were taken from nonbearing one-year-old shoots to evaluate the nutritional status of the trees. In the autumn of 2017 (November $27^{\text {th }}$ ) and 2018 (November $19^{\text {th }}$ ) young fully expanded leaves were collected from all quarters of the trees and taken to the laboratory for evaluation of the incidence of olive leaf spot disease. At the same time, samples of olives from all quarters were also taken and sent to the laboratory for determination of pulp nutrient concentration and the incidence of olive fruit fly and olive anthracnose. Thereafter, the experimental plots were harvested for olive yield evaluation. The olives were detached by a portable olive tree shaker and recovered in a net lying on the floor. Olive yields were recorded per tree. A maturity index of fruits was also recorded at harvest from random samples of 50 fruits per cultivar and nitrogen treatment, by using the extended $\mathrm{BBCH}$ (Biologische Bundesanstalt, Bundessortnamt and CHemical industry) scale of Meier (2001).

\subsection{Laboratorial determinations}

The leaf samples taken in July and December and the pulps of subsamples of olives taken at harvest were analyzed for elemental composition, after having been oven-dried at $70{ }^{\circ} \mathrm{C}$ and ground. Tissue analyses were performed by Kjeldahl (nitrogen), colorimetry (boron and phosphorus), flame emission spectrometry (potassium) and atomic absorption spectrophotometry (calcium, magnesium, copper, iron, zinc, and manganese) methods (Walinga et al., 1989), after tissue samples were digested with nitric acid in a microwave.

Fruits infected by olive anthracnose and infested by olive fruit fly (eggs, larvae and exit holes) were examined in both the years from samples of 50 random fruits per experimental unit taken at harvest. To check the fruits for olive anthracnose, each diseased fruit was cut into five segments $(3 \times 3 \mathrm{~mm})$ and the segments transferred to $70 \%$ alcohol solution for $2 \mathrm{~min}$. After being dried on sterile filter paper the segments were placed in PDA (Potato Dextrose Agar, Difco, $39 \mathrm{~g} \mathrm{~L}^{-1}$ ) plates for mycelial growth. The plates were incubated at $25 \pm 2{ }^{\circ} \mathrm{C}$ in the dark for five days. The identification of olive anthracnose isolates was performed by analysing morphological characteristics under binocular microscope. For the determination of olive fruit fly infestation, the fruits were observed with a binocular microscope, and the number of immature stages, eggs, young larvae, that included the first-instar larvae (L1) and second-instar larvae (L2), mature larvae (third-instar larvae, L3), pupae, as well as exit holes, recorded. The results of diseased fruits and drupes attacked by olive fruit fly were expressed in percentage terms.

Olive leaf spot was assessed from 50 young fully developed leaves, randomly selected in all quadrants of the trees. The incidence and severity of disease was determined by visual observation of olive leaf spot symptoms and by observation after submerging the leaves in a $5 \%$ $\mathrm{NaOH}$ solution for $25 \mathrm{~min}$. The severity of the disease was evaluated by applying a scale of 1 to 5 , with the lowest value being the absence of symptoms and the highest value, more than 5 spots per leaf, following the methodology proposed by Gouveia et al. (1998). For the evaluation of severity was considered by inspection of visible symptoms on the leaves, both untreated and also after submerging in a $5 \% \mathrm{NaOH}$ solution for $25 \mathrm{~min}$.

\subsection{Data analysis}

Data of olive yield, fruit size and tissue nutrient concentrations was analyzed for normality and homogeneity of variances using the Shapiro-Wilk test and Bartlett's test, respectively. Data was then subjected to analysis of variance according to the completely randomized design. When significant differences were found $(\alpha<0.05)$, the means were separated by the multiple range Tukey HSD $(\alpha=0.05)$ test. The average values of incidence of olive fruit fly and diseases of fruits and leaves were compared by their confidence intervals $(\alpha=0.05)$.

\section{Results}

\subsection{Olive fruit fly}

The incidence of olive fruit fly was higher in 'Madural' particularly in 2017 (Fig. 2). The percentage of incidence, if eggs, larvae, pupae and 

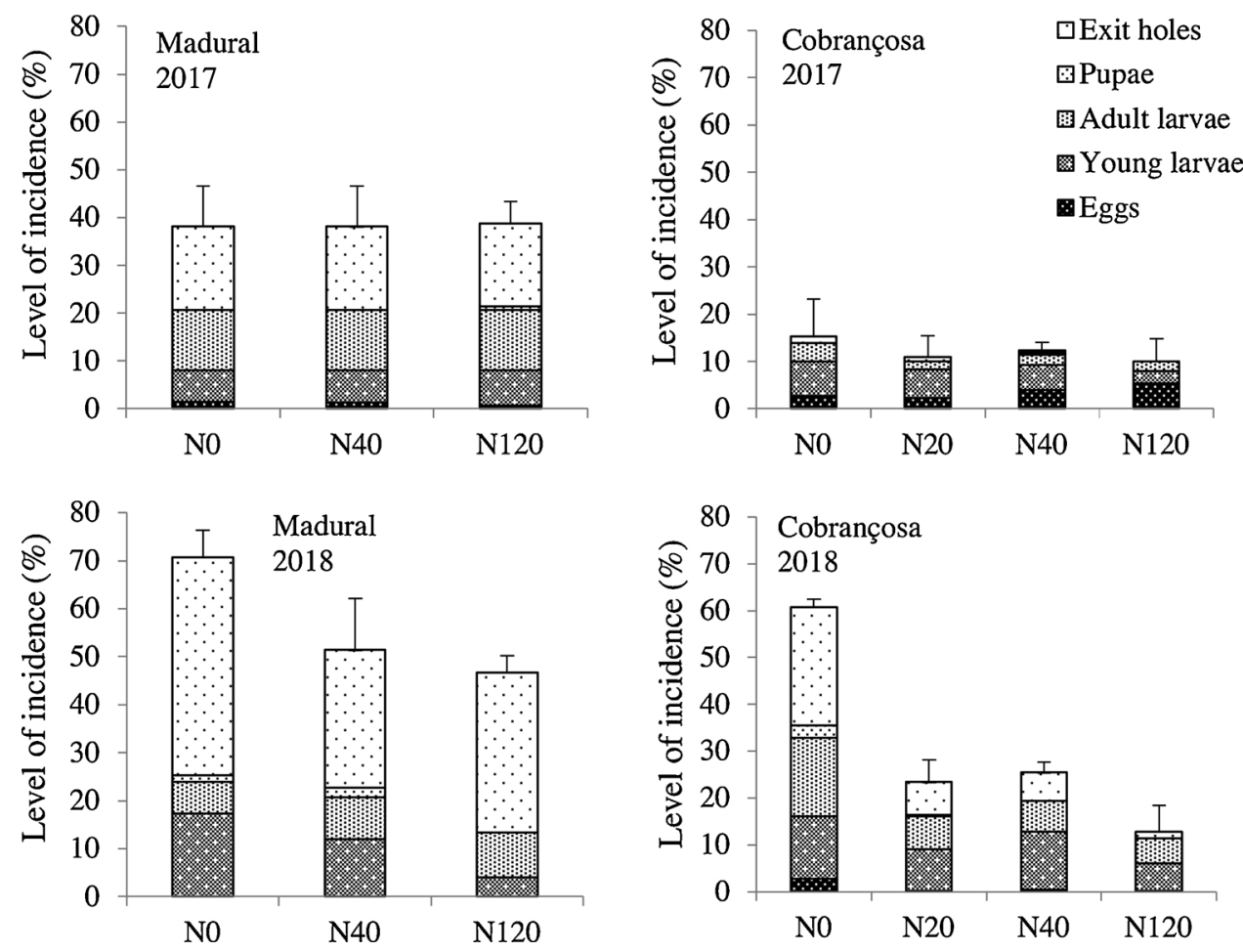

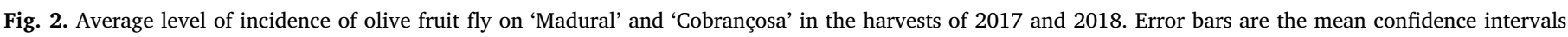
$(\alpha=0.05)$ for total attack (different forms of insect and exit holes).

exit holes were included, varied between $38.1-38.7 \%, 10.0-15.3 \%$, $46.7-70.7 \%$ and $12.7-60.7 \%$, respectively in 'Madural' 2017, 'Cobrançosa' 2017, 'Madural' 2018 and 'Cobrançosa' 2018. In 'Cobrançosa' in 2017 and in both cultivars in 2018, the higher and lower levels of incidence were respectively found in the control treatment and in the N120, the most fertilized treatment. Thus, nitrogen fertilization seems to have a marked effect in reducing the incidence of olive fruit fly in three of the four situations analyzed.

The incidence of olive anthracnose was higher in 2018 compared to 2017 in both cultivars (Fig. 3). The level of incidence varied between $8.7-15.3 \%, 9.7-31.3 \%, 2.8-8.0 \%$ and $0.7-4.7 \%$, respectively in 'Madural' 2017, 'Cobrançosa' 2017, 'Madural' 2018 and 'Cobrançosa' 2018. No consistent trend was observed in response to the increased rate of nitrogen applied.

In 2017, 'Madural' displayed very low levels of olive leaf spot incidence, not exceeding 4.7\% even when incubated with $\mathrm{NaOH}$ (Fig. 4). However, in the same year, incidence rates in 'Cobrançosa' are much higher, reaching $54.0 \%$ of leaves infected with the disease. In 2018 the values are of the same order of magnitude in the two cultivars, in 'Madural' ranging between $24.5 \%$ and $36.9 \%$ and in the 'Cobrançosa' between $14.0 \%$ and $44.7 \%$. Only in 2017 and in 'Cobrançosa' the disease had sufficient development to be detected visually on a relevant number of leaves. In none of the years or cultivars a clear relationship was observed between disease incidence and nitrogen rates.

When the leaves with symptoms of the disease were separated into levels of severity it was possible to observe that there is a pattern that is repeated. Whenever the disease is present, several spots per leaf are frequently found, although these decrease in number between the classes 1 leaf spot and $>5$ leaf spots (Fig. 5).

The cumulative olive yields in the two successive crops increased significantly with the nitrogen rate in both cultivars (Fig. 6). The olive yields were higher in 2018 compared to 2017, in particular in the cultivar 'Madural', as also were the differences between treatments. The accumulated olive yields $(2017+2018)$ varied between 29.6 and $43.7 \mathrm{~kg}$ tree ${ }^{-1}$ between the treatments N0 and N120 in 'Madural' and between 29.1 and $52.9 \mathrm{~kg}^{-1} \mathrm{tree}^{-1}$ in 'Cobrançosa'.
In 2017, the fruit size did not significantly vary with nitrogen rate in any of the cultivars (Fig. 7). However, the results of 'Cobrançosa' seem to show a consistent decrease, a tendency in contrast to that observed in olive yield. In 2018, the fruit size significantly decreased with the increase in nitrogen rate in both cultivars, in contrast to the observed increase in olive yield.

The maturity index was low in the most fertilized plots with the exception of the cultivar 'Madural' in 2018, where the harvest was made in late November when all the fruits had already reached the typical colour of the variety. The fruits of 'Madural' get their typical variety colour earlier in the autumn than 'Cobrançosa'.

Leaf nitrogen concentration significantly increased with nitrogen rates in both cultivars and for each year (Fig. 8). Leaf $\mathrm{N}$ concentrations in the control treatments were in the deficient range. Only in the N120 treatment did the levels of nitrogen in the leaves persist within the sufficiency range established for olive. The treatments N20 and N40 led to leaf $\mathrm{N}$ concentrations close to the lower limit of the sufficiency range. The results of the other nutrients analyzed showed little variation with nitrogen treatments. Only calcium levels significantly decreased with nitrogen rates in 'Madural' but not in 'Cobrançosa' (data not shown).

The nitrogen concentrations in the pulp also increased with nitrogen rates in both cultivars (Fig. 9). In the most fertilized trees, the concentration of nitrogen in the pulp slightly decreased from 2017 to 2018 , in an opposite direction to olive yield. Other essential elements for plant growth found in the pulp showed even less variation with nitrogen rates than that found in the leaves (data not shown).

\section{Discussion}

The higher rates of nitrogen reduced the risk of attack by olive fruit fly in both cultivars, with 'Cobrançosa' recording lower incidence levels than 'Madural'. The fruits of trees under severe drought stress tended to show characteristic wrinkling and delayed maturation. Nitrogen fertilization tended to increase the vegetative expansion of the trees in the spring and consequently to accentuate the drought stress in late summer in rainfed orchards, due to the greater surface-area created for 

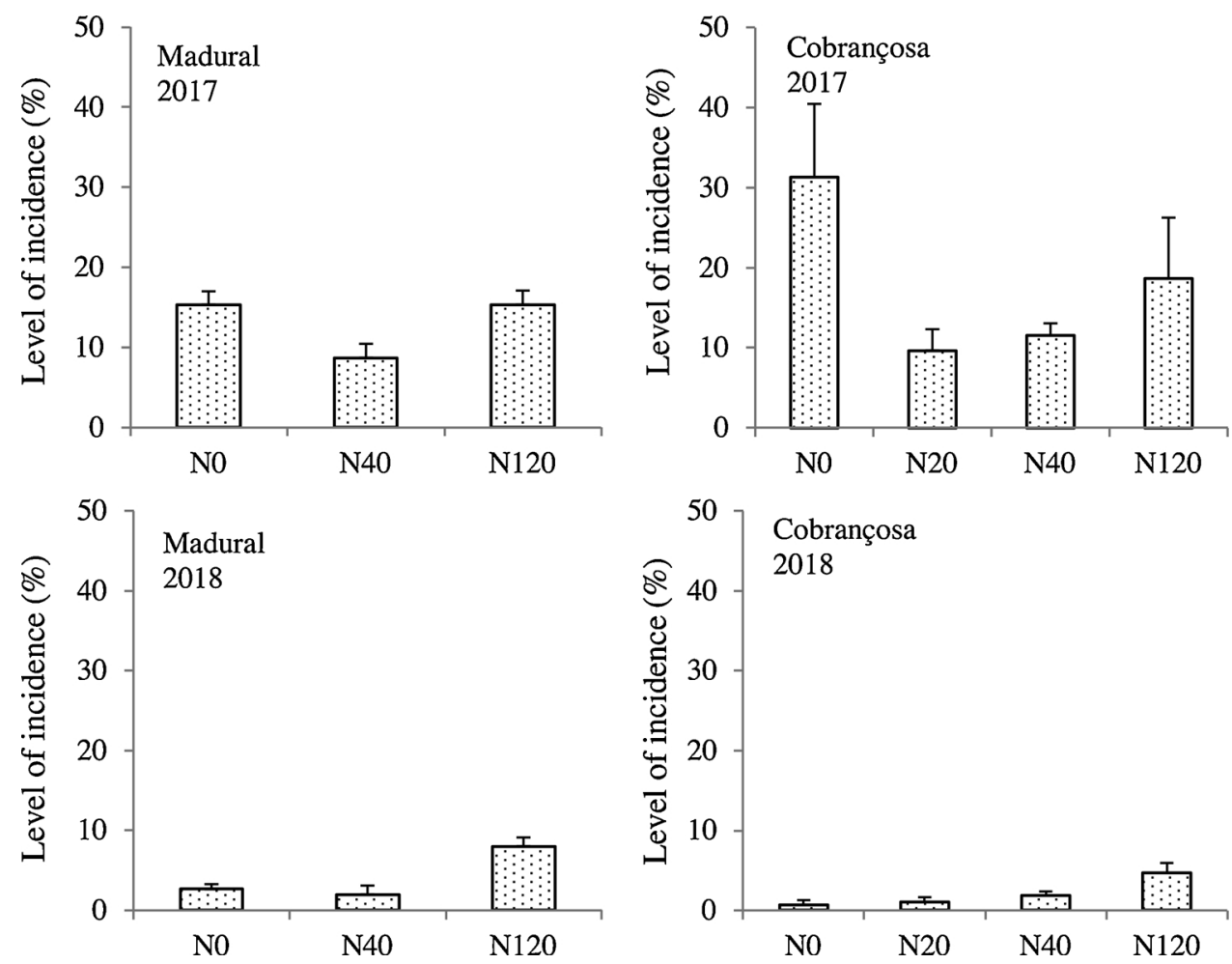

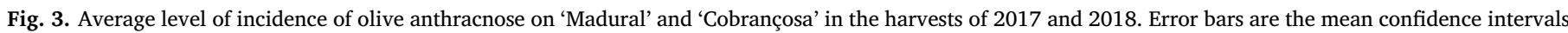
$(\alpha=0.05)$.

transpiration. Fruit maturation was also delayed with nitrogen rates as the fruit load increased (Table 2). Thus, the delay in maturation was probably the reason for the lower incidence of olive fruit fly in the more fertilized trees. It should be borne in mind that the insect's peak flight in the region corresponds to the first half of October occurring until the
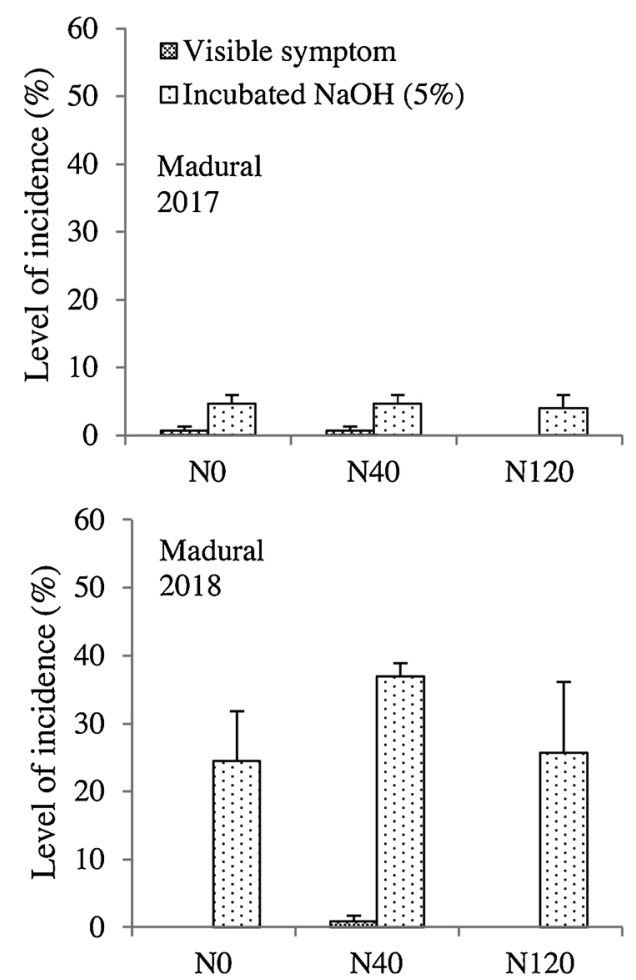

beginning of November (Bento et al., 1999; Coelho et al., 2010). 'Madural' is known to be a cultivar which is very susceptible to attack by olive fruit fly and 'Cobrançosa' much less so (Bento et al., 2009). It is also worth noting that 'Madural' is more precocious than 'Cobrançosa'. These results also seem to indicate that the sensitivity of 'Madural' to
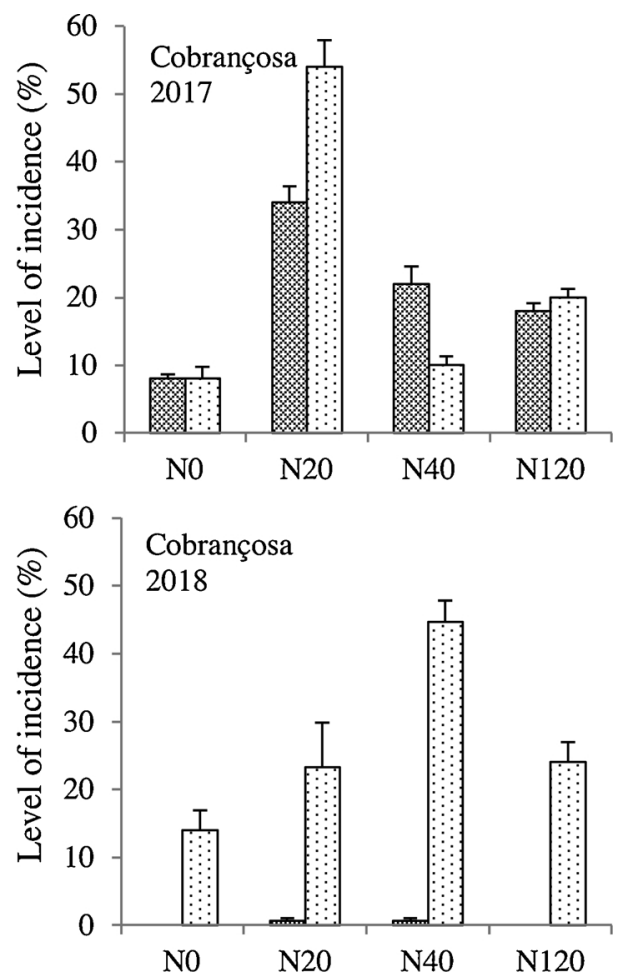

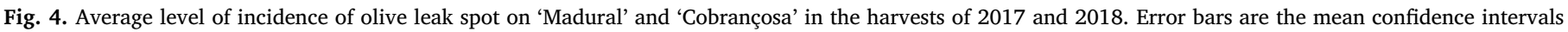
$(\alpha=0.05)$. 

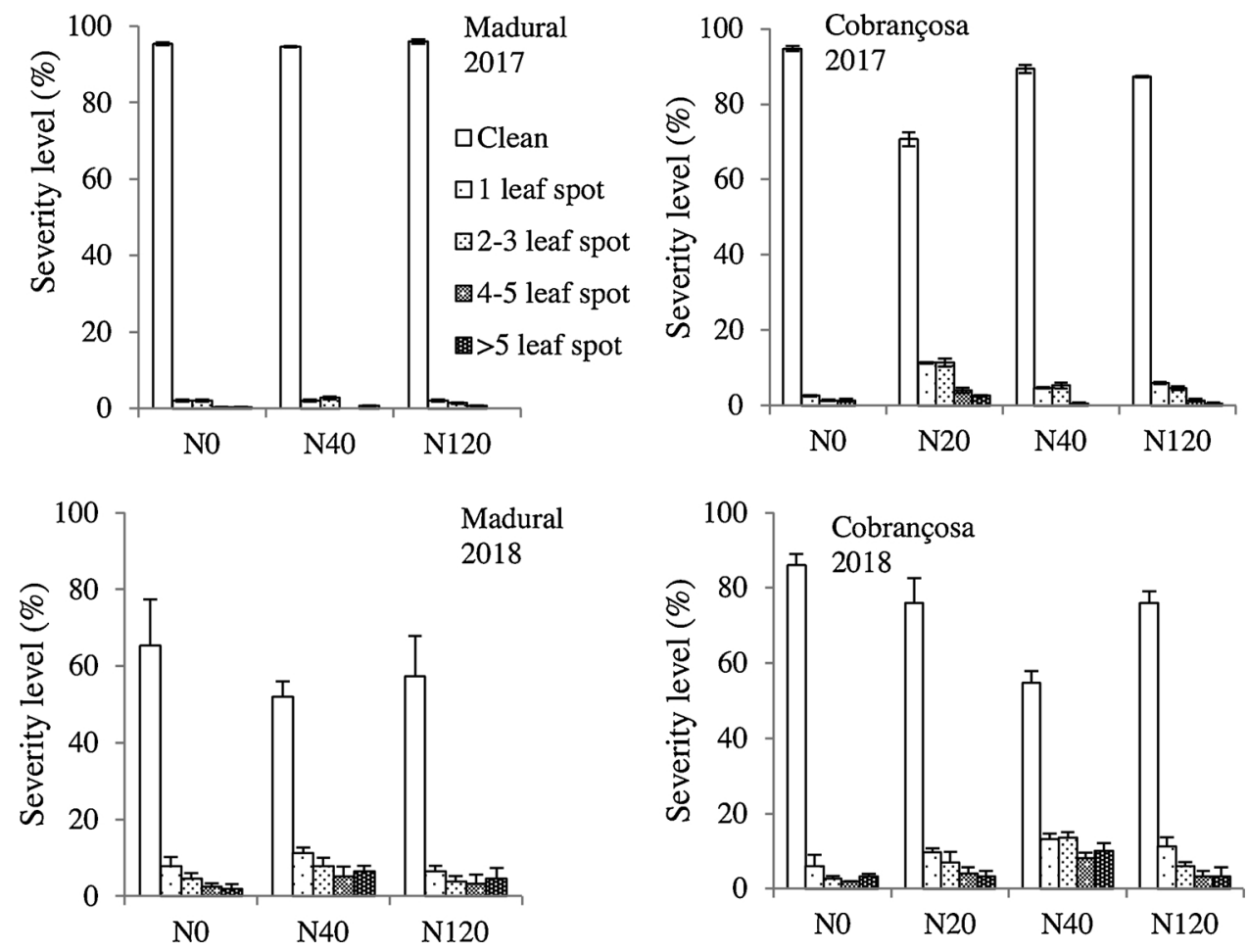

Fig. 5. Severity of olive leaf spot disease on 'Madural' and 'Cobrançosa' in the harvests of 2017 and 2018. Error bars are the mean confidence intervals ( $\alpha=0.05$ ).

attack by olive fruit fly might be due to the phenology of fruit maturity being more coincident with the active period of insect egg-laying. The composition of the fruits also changed with nitrogen rate (Fig. 9). The effect of nitrogen on the formation of several volatile organic compounds, which may be attractive or repellent to the insects, is known in other crops (Veromann et al., 2013). It may be that the change in fruit composition by the application of nitrogen has a negative influence on the laying of eggs by the insect.

In the experimental orchards unfertilized trees coexisted with fertilized trees, which gives a different situation from what occurs in commercial olive groves where all the trees are fertilized in the same way. Thus, in a uniformly fertilized commercial olive grove, the insects cannot choose one tree over another to lay their eggs based on a different composition of the fruits. However, if the main reason for the reduction in egg-laying is the desynchronization of the fruit maturity with the flight curve of the insect, an effective reduction in egg-laying could occur, whenever the maturation is delayed. What emerges from this result as more relevant is that the activity of the olive fruit fly is not helped by the use of high nitrogen rates. Thus, nutrient management in olive groves must balance the requirements of economic rationality and environmental preservation, particularly with regard to the harmful relationship between the use of excessive nitrogen rates and several aspects of environmental contamination, such as ammonia volatilization, nitrate leaching and denitrification (Scherer and Mengel, 2007; Havlin et al., 2014).

The incidence of olive anthracnose did not show a consistent pattern among nitrogen treatments nor between cultivars, with results varying during the two years analyzed. Neither the composition of the fruit, nor a denser canopy, nor the delay in maturation appears to have had a significant effect on the incidence of this disease. Several environmental variables may have contributed to the experimental variability found. In 2017 the incidence of diseases may have been higher following a particularly hot October. Considering the limited number of trees used in these types of studies, localized infections have the potential to introduce a great deal of experimental variability and overlap to the effect of treatments. It has long been recognized that the nutritional status of a plant can play a role in its susceptibility to pathogenic fungi. Studies have shown how nitrogen fertilization may aggravate the incidence of some diseases (Heier et al., 2005; Santos et al., 2009; Hemissi et al., 2018), but the incidence of other diseases seems to be mitigated by good plant nutritional status (Lecompte et al., 2010; Cao et al., 2013; Krnjaja et al., 2015; Zimerman-Lax et al., 2016). In this study it was not possible to establish a relationship between olive anthracnose and nitrogen rates in any of the cultivars.
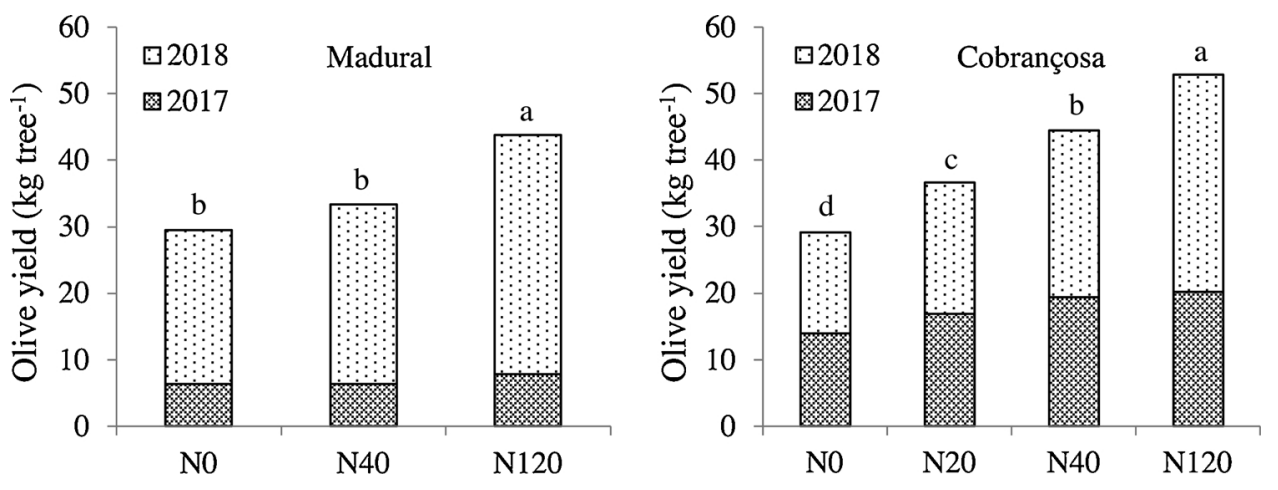

Fig. 6. Average olive yield per tree on 'Madural' and 'Cobrançosa' olive orchards in the harvests of 2017 and 2018. Letters above the columns are the result of the analysis of variance and the separation of the means by Tukey HSD test $(\alpha=0.05)$ when significant differences among treatments for olive yield accumulation $(2017+2018)$ were found. 

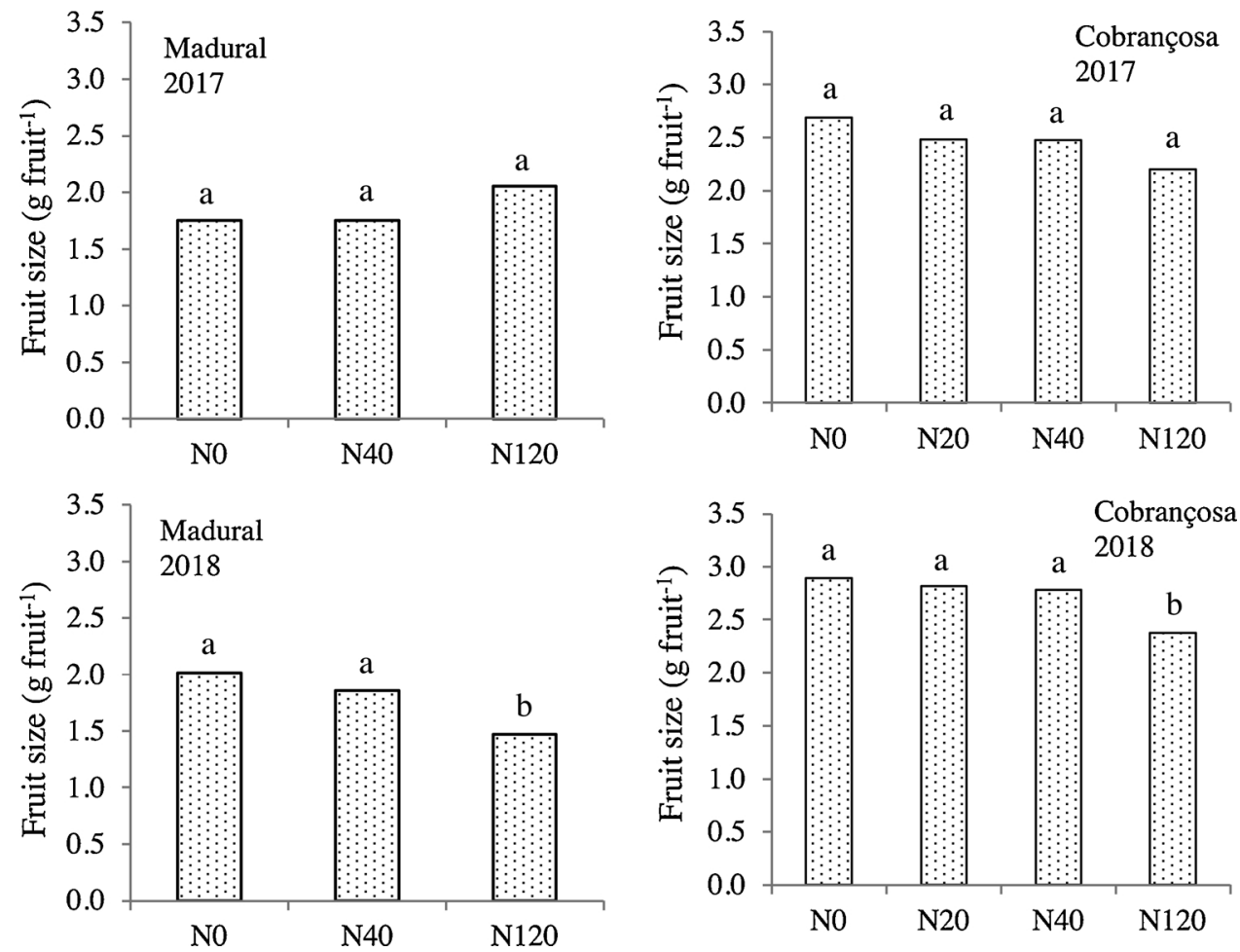

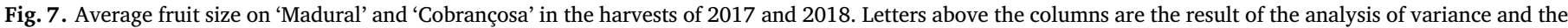
separation of the means by Tukey HSD test $(\alpha=0.05)$ when significant differences among treatments were found.

The incidence of olive leaf spot also significantly varied between years and between experimental plots, but without a clear relationship with nitrogen fertilizer treatments. Like olive anthracnose, olive leaf spot also showed little sensitivity to the nitrogen fertilization and the changes that the nutrient generated in leaf composition and consequently the structure of the canopy. Once again, other variables, such as precipitation or relative humidity may be more relevant to the spread of this disease than nitrogen fertilization. However, previous studies with the susceptible cultivar 'Picual' using plants or detached leaves artificially inoculated with a conidial suspension of the pathogen have shown significant increase in shoot growth, nitrogen concentration in leaves, and disease incidence in plants, subjected to high nitrogen rates (Roca et al., 2018).

Nitrogen fertilization had a very marked effect on the tree. Productivity increased significantly in both cultivars. Nitrogen concentration in leaves and fruits also increased. Although there are studies that have shown a lack of response by the olive tree to nitrogen fertilization (Fernández-Escobar et al., 2009a, b), the results of this study are in agreement with several others found in the literature where olive yield increased with nitrogen fertilization (Erel et al., 2013; MoralesSillero et al., 2009; Rodrigues et al., 2011, 2015). Fruit size reduced as the nitrogen rate and crop load increased.

\section{Conclusions}

Nitrogen fertilization significantly increased olive yield and consequently delayed fruit maturation. Nitrogen significantly reduced the incidence of the olive fruit fly, being the result of delays in fruit maturity, which might have desynchronized the presence of attractive fruits for egg-laying with the flight curve of the insect. 'Madural' was more susceptible to the attack of olive fruit fly than 'Cobrançosa', probably because it is an early maturing cultivar. Nitrogen fertilization showed no relation to the incidence of olive leaf spot and olive anthracnose. Thus, the working hypotheses set in the introduction section that nitrogen fertilization increases the incidence of olive fruit fly, olive leaf spot and olive anthracnose has not been confirmed.

\section{Acknowledgments}

The authors are grateful to the Foundation for Science and Technology (FCT, Portugal) and European Agricultural Fund for Rural Development (EAFRD) under the Programme PT2020 for financial

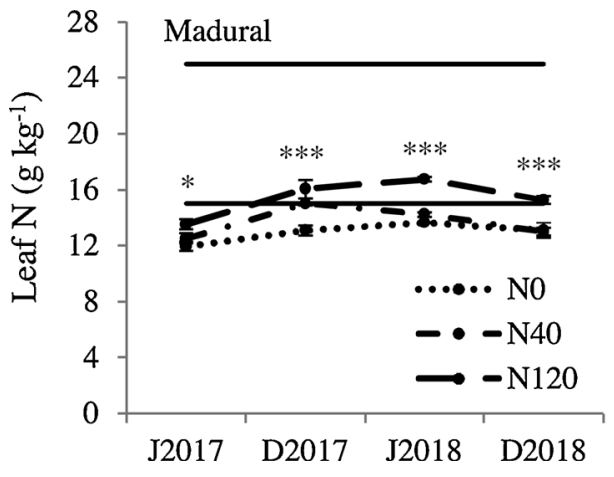

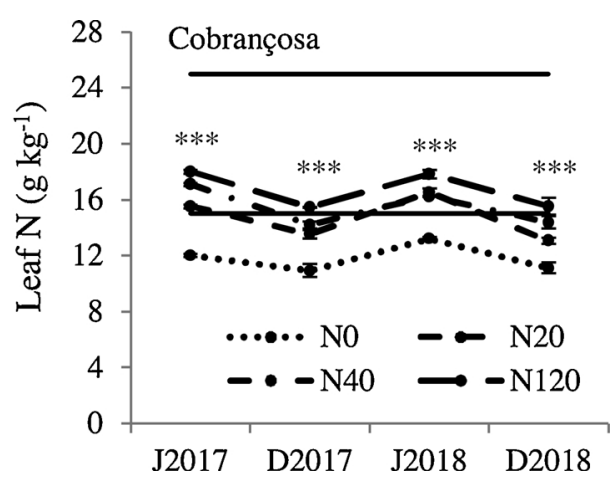

Fig. 8. Leaf nitrogen concentration on 'Madural' and 'Cobrançosa' from samples taken in July (J) and December (D) 2017 and 2018. Horizontal lines are the higher and lower limits of the sufficiency ranges for summer leaf sampling after Bryson et al. (2014). *, ***, significant, respectively, at $P<0.05$ and $P<0.001$. Error bars are the mean confidence intervals $(\alpha=0.05)$. 

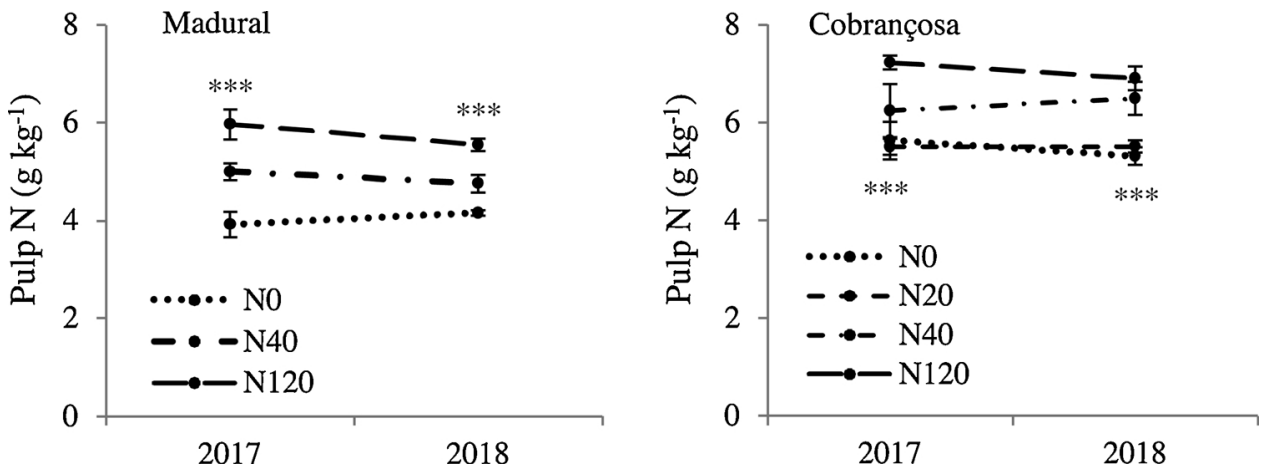

Fig. 9. Pulp nitrogen concentrations on 'Madural' and 'Cobrançosa' from samples taken in the harvests of 2017 and 2018. ***, significant at $P<0.001$. Error bars are the mean confidence intervals $(\alpha=0.05)$.

Table 2

Maturity index based on the extended BBCH (Biologische Bundesanstalt, Bundessortnamt and CHemical industry) phenological scale of Meier (2001).

\begin{tabular}{llll}
\hline Year & Cultivar & N treatment & Maturity índex* \\
\hline \multirow{3}{*}{2017} & Madural & N0 & 89 \\
& & N120 & 89 \\
& Cobrançosa & N0 & 88 \\
& & N120 & 87 \\
2018 & Madural & N0 & 88 \\
& & N120 & 87 \\
& Cobrançosa & N0 & 86 \\
& & N120 & 85
\end{tabular}

* Gradients between 85 (increasing specific fruit colouring) and 89 (harvest maturity: fruits get the typical variety colour, remaining turgid, suitable for oil extraction).

support to Centro de Investigação de Montanha, CIMO (UID/AGR/ 00690/2015) and Project 023721 (02/SAICT/2016) "BioSave: Promoção do potencial económico e da sustentabilidade dos setores do azeite e da castanha".

\section{References}

Aigu, Y., Laperche, A., Mendes, J., Lariagon, C., Guichard, S., Gravot, A., ManzanaresDauleux, M.J., 2018. Nitrogen supply exerts a major/minor switch between two QTLs controlling Plasmodiophora brassicae spore content in Rapeseed. Plant Pathol. 67, $1574-1581$.

Alvarado, M., Campos, M., Civantos, M., Durán, J.M., Ruiz, M.J., 2017. Plagas. In: Barranco, D., Fernández-Escobar, R., Rallo, L. (Eds.), El Cultivo del Olivo., 7th ed. Mundi-Prensa, Madrid, Spain, pp. 642-732.

Arrobas, M., Parada, M.J., Magalhães, P., Rodrigues, M.A., 2011. Nitrogen-use efficiency and economic efficiency of slow-release $\mathrm{N}$ fertilisers applied to irrigated turfs in a Mediterranean environment. Nutr. Cycl. Agroecosys. 89, 329-339.

Bento, A., Pereira, J.A., Cabanas, J., Pinto, A., Torres, L., 2009. Sensibilidade de diferentes cultivares de oliveira aos ataques da mosca da azeitona, Bactrocera oleae, e da traça da oliveira, Prays oleae. Proc. III Simpósio Nacional de Olivicultura 134-140.

Bento, A., Pereira, S., Armendáriz, I., Pereira, J.A., 1999. A mosca-da-azeitona, Bactrocera oleae (Gmelin), no Planalto Mirandês: ciclo biológico e importância económica. Proc. I Congresso Nacional de Produção Integrada 191-198.

Bronson, K.F., 2008. Forms of inorganic nitrogen in soils. In: Schepers, J.S., Raun, W.R. (Eds.), Nitrogen in Agricultural Systems. Agronomy Monograph n.ำ 49. ASA, CSSA, SSSA, Madison, WI, USA, pp. 31-55.

Bryson, G., Mills, H.A., Sasseville, D.N., Jones Jr, J.B., Barker, A.V., 2014. Plant Analysis Handobook III. A Guide to Sampling, Preparation, Analysis and Interpretation for Agronomic and Horticultural Crops. Micro-Macro Publishing, Inc., Athens, GA.

Cao, T., Duncan, R.A., Kirkpatrick, B.C., Shackel, K.A., Dejong, T.M., 2013. Effect of calcium and nitrogen fertilization on bacterial canker susceptibility in stone fruits. Fruits 68, 245-254.

Carretero, R., Bancal, M.O., Miralles, D.J., 2011. Effect of leaf rust (Puccinia triticina) on photosynthesis and related processes of leaves in wheat crops grown at two contrasting sites and with different nitrogen levels. Eur. J. Agron. 35, 237-246.

Coelho, V.P., Bento, A., Mexia, A., Pereira, J.E., 2010. Olive fruit fly, bactrocera oleae (gmelin), mass-trapping with olipe traps: effect of hole size in the olive fruit fly and nontarget arthropod captures. Proc. 8th Intern. Symposium on Fruit Flies of Economic Importance 334-341.

Covas, M.A., 2007. Olive oil and the cardiovascular system. Pharmacol. Res. 55, 175-186.

Coyne, M.S., 2008. Biological denitrification. In: Schepers, J.S., Raun, W.R. (Eds.),
Nitrogen in Agricultural Systems. Agronomy Monograph n. ${ }^{\circ 49}$. ASA, CSSA, SSSA, Madison, WI, USA, pp. 201-253.

David, M., Swiader, J., Williams, K., Eastburn, D., 2003. Nitrogen nutrition, but not potassium, affects powdery mildew development in Hiemalis Begonia. J. Plant Nutr. 26 (1), 159-176.

Erel, R., Yermiyahu, U., Van Opstal, J., Ben-Gal, A., Schwartz, A., Dag, A., 2013. The importance of olive (Olea europaea L.) tree nutritional status on its productivity. Sci. Hortic. 159, 8-18.

Espejo-Herrera, N., Cantor, K.P., Malats, N., Silverman, D.T., Tardón, A., García-Closas, R., Serra, C., Kogevinas, M., Villanueva, C.M., 2015. Nitrate in drinking water and bladder cancer risk in Spain. Environ. Res. 137, 299-307.

Fernández-Escobar, R., Marin, L., Sánchez-Zamora, M.A., García-Novelo, J.M., MolinaSoria, C., Parra, M.A., 2009a. Long-term effects of $\mathrm{N}$ fertilization on cropping and growth of olive trees and on $\mathrm{N}$ accumulation in soil profile. Eur. J. Agron. 31, $223-232$.

Fernández-Escobar, R., Parra, M.A., Navarro, C., Arquero, O., 2009b. Foliar diagnosis as a guide to olive fertilization. Span. J. Agric. Res. 7, 212-223.

Gash, A.F.J., 2012. Wheat nitrogen fertilisation effects on the performance of the cereal aphid Metopolophium dirhodum. Agronomy 2, 1-13.

Gouveia, M.E., Coelho, V., Bento, A., 1998. O olho de pavão (Spilocaea oleagina) na região de Mirandela. Distribuição, incidência, severidade e densidade de inóculo. Rev. Cienc. Agrar. 21, 287-294.

Havlin, J.L., Tisdale, S.L., Nelson, W.L., Beaton, J.D., 2014. Soil Fertility and Fertilizers, an Introduction to Nutrient Management, 8th edition. Pearson, Inc, New Jersey, USA.

Heier, T., Jain, S.K., Kogel, K.-H., Pons-Kühnemann, J., 2005. Influence of N-fertilization and fungicide strategies on fusarium head blight severity and mycotoxin content in winter wheat. J. Phytopathol. 153, 551-557.

Hemissi, I., Gargouri, S., Hlel, D., Hachana, A., Abdi, N., Sifi, B., 2018. Impact of nitrogen fertilization on Fusarium foot and root rot and yield of durum wheat. Tunis. J. Plant Prot. 13 (si), 31-38.

Krnjaja, V., Mandi, V., Levi, J., Stankovi, S., Petrovi, T., Vasi, T., Obradovi, A., 2015. Influence of $\mathrm{N}$-fertilization on Fusarium head blight and mycotoxin levels in winter wheat. Crop Prot. 67, 251-256.

Lecompte, F., Abro, M.A., Nicot, P.C., 2010. Contrasted responses of Botrytis cinerea isolates developing on tomato plants grown under different nitrogen nutrition regimes. Plant Pathol. 59, 891-899.

Medeiros, M.D., 2001. Olive oil and health benefits. In: Wildman, R.E.C. (Ed.), The Handbook of Nutraceuticals and Functional Foods. CRC Press, Boca Raton, FL, pp. 261-267.

Meier, U., 2001. Growth stages of mono- and dicotyledonous plants. BBCH monographs. Federal Biological Research Centre for Agriculture and Forestry, 2nd ed. BBCH Publ, Germany.

Morales-Sillero, A., Fernández, J.E., Ordovás, J., Suárez, M.P., Pérez, J.A., Liñán, J., López, E.P., Girón, I., Troncoso, A., 2009. Plant-soil interactions in a fertigated 'Manzanilla de Sevilla' olive orchard. Plant Soil 319, 147-162.

Mulla, D.J., Strock, J.S., 2008. Nitrogen transformation process in soils. In: Schepers, J.S. Raun, W.R. (Eds.), Nitrogen in Agricultural Systems. Agronomy Monograph n. ${ }^{\circ} 49$. ASA, CSSA, SSSA, Madison, WI, USA, pp. 361-400.

Oerte, E.-C., Schönbeck, F., 1990. Effect of nitrogen and powdery mildew on the yield formation of two winter barley cultivars. J Phytopathol. 130, 89-104.

Pérez-Jiménez, F., Ruano, J., Perez-Martinez, P., Lopez-Segura, F., Lopez-Miranda, J., 2007. The influence of olive oil on human health: not a question of fat alone. Mol. Nutr. Food Res. 51, 1199-1208.

Poikane, S., Phillips, G., Birk, S., Free, G., Kelly, M.G., Willby, N.J., 2019. Deriving nutrient criteria to support 'good' ecological status in European lakes: an empirically based approach to linking ecology and management Sci. Total Environ. 650, 2074-2084.

Robert, C., Bancal, M.-O., Lannou, C., Ney, B., 2006. Quantification of the effects of Septoria tritici blotch on wheat leaf gas exchange with respect to lesion age, leaf number, and leaf nitrogen status. J. Exp. Bot. 57, 225-234.

Robert, C., Bancal, M.-O., Ney, B., Lannou, C., 2005. Wheat leaf photosynthesis loss due to leaf rust, with respect to lesion development and leaf nitrogen status. New Phytol. $165,227-241$.

Rodrigues, M.A., Dimande, P., Pereira, E., Ferreira, I.Q., Freitas, S., Correia, C.M., Moutinho-Pereira, J., Arrobas, M., 2015. Early-maturing annual legumes: an option 
for cover cropping in rainfed olive orchards. Nutr. Cycl. Agroecosys. 103, 153-166. Rodrigues, M.A., Pereira, A., Cabanas, J.E., Dias, L., Pires, J., Arrobas, M., 2006. Crops use-efficiency of nitrogen from manures permitted in organic farming. Eur. J. Agron. 25, 328-335.

Rodrigues, M.A., Coutinho, J., Martins, J., Arrobas, M., 2005. Quantitative sidedress nitrogen recommendations for potatoes based upon crop nutritional indices. Eur. J. Agron. 23, 79-88.

Rodrigues, M.A., Pavão, F., Lopes, J.I., Gomes, V., Arrobas, M., Moutinho-Pereira, J., Ruivo, S., Cabanas, J.E., Correia, C.M., 2011. Olive yields and tree nutritional status during a four year period without nitrogen and boron fertilization. Commun. Soil Sci. Plant Anal. 42, 803-814.

Santos, G.R., Castro Neto, M.D., Almeida, H.S.M., Ramos, L.N., Sarmento, R.A., Lima, S.O., Erasmo, E.A.L., 2009. Effect of nitrogen doses on disease severity and watermelon yield. Hortic. Bras. 27, 330-334.

Scherer, H.W., Mengel, K., 2007. Ullmann's Agrochemicals. Fertilizers, vol. 3 Wiley-VCH Verlag GmbH \& Co, KGaA, Weinheim Chapter 2.

Schullehner, J., Birgitte, H., Thygesen, M., Pedersen, C.B., Sigsgaard, T., 2018. Nitrate in drinking water and colorectal cancer risk: a nationwide population-based cohort study. Int. J. Cancer 143, 73-79.

Trapero, A., López, F.J., Blanco, M.A., 2017. Enfermedades. In: Barranco, D., Fernández-
Escobar, R., Rallo, L. (Eds.), El Cultivo del Olivo, 7th ed. Mundi-Prensa, Madrid, Spain, pp. 733-798.

Usanmaz, S., Öztürkler, F., Helvaci, M., Alas, T., Kahramanoğlu, I., Aşkin, M., 2018 Effects of periods and altitudes on the phenolic compounds and oil contents of olives, cv. ayvalik. Int. J. Agric. For. Life Sci. 2 (2), 32-39.

Veromann, E., Toome, M., Kännaste, A., Kaasik, R., Copolovici, L., Flink, J., Kovács, G., Narits, L., Luik, A., Niinemets, Ü., 2013. Effects of nitrogen fertilization on insect pests, their parasitoids, plant diseases and volatile organic compounds in Brassica napus. Crop Prot. 43, 79-88.

Vos, J.G.M., Frinking, H.D., 1997. Nitrogen fertilization as a component of integrated crop management of hot pepper (Capsicum spp.) under tropical lowland conditions. Int. J. Pest Manage 43, 1-10.

Walinga, I., van Vark, W., Houba, V., van der Lee, J., 1989. Soil and Plant Analysis: Part 7 - Plant Analysis Procedures. Wageningen Agricultural University, The Netherlands.

Yang, X., Zhang, P., Li, W., Hu, C., Zhang, X., He, P., 2018. Evaluation of four seagrass species as early warning indicators for nitrogen overloading: implications for eutrophic evaluation and ecosystem management. Sci. Total Environ. 635, 1132-1143.

Zimerman-Lax, N., Shenker, M., Tamir-Ariel, D., Perl-Treves, R., Burdman, S., 2016. Effects of nitrogen nutrition on disease development caused by Acidovorax citrulli on melon foliage. Eur. J. Plant Pathol. 145, 125-137. 